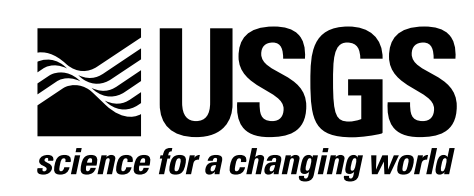

\title{
Change in the Length of the Southern Section of the Chandeleur Islands Oil Berm, January 13, 2011, through September 3, 2012
}

By N.G. Plant and K.K. Guy

Open-File Report 2013-1303

U.S. Department of the Interior

U.S. Geological Survey 


\section{U.S. Department of the Interior \\ SALLY JEWELL, Secretary}

\section{U.S. Geological Survey \\ Suzette M. Kimball, Acting Director}

U.S. Geological Survey, Reston, Virginia: 2014

For more information on the USGS—-the Federal source for science about the Earth, its natural and living resources, natural hazards, and the environment-visit http://www.usgs.gov or call 1-888-ASK-USGS

For an overview of USGS information products, including maps, imagery, and publications, visit http://www.usgs.gov/pubprod

To order this and other USGS information products, visit http://store.usgs.gov

Any use of trade, firm, or product names is for descriptive purposes only and does not imply endorsement by the U.S. Government.

Although this information product, for the most part, is in the public domain, it also may contain copyrighted materials as noted in the text. Permission to reproduce copyrighted items must be secured from the copyright owner.

Suggested citation:

Plant, N.G., and Guy, K.K., 2014, Change in the Length of the Southern Section of the Chandeleur Islands Oil Berm, January 13, 2011, through September 3, 2012: U.S. Geological Survey Open-File Report 2013-1303, 8 p., http://dx.doi.org/10.3133/ofr20131303

ISSN 2331-1258 (online) 


\section{Contents}

Introduction

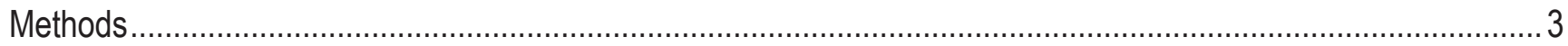

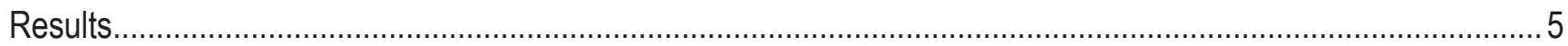

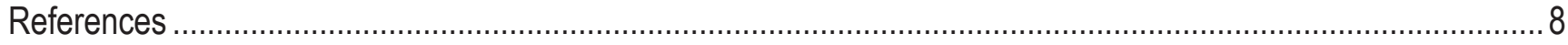

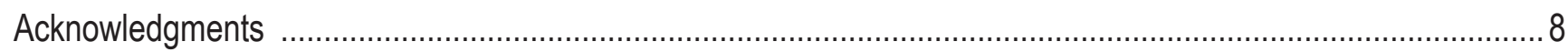

\section{Figures}

1. Chandeleur and Breton Islands (part of the Breton Island National Wildlife Refuge), the Mississippi River Delta, the site of the Deepwater Horizon oil spill, and the location of the full extent of the

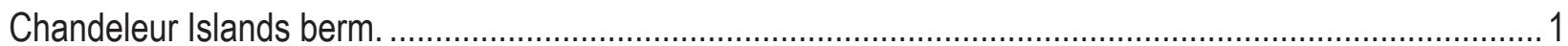

2. The Chandeleur Islands berm divided into northern, middle, and southern sections................................. 2

3. The completed southern section of the Chandeleur Islands berm ............................................................ 2

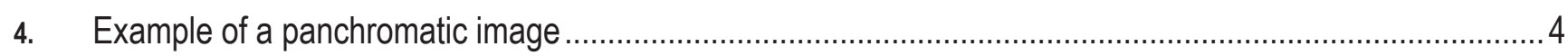

5. Example of isolines generated on the basis of pixel value .................................................................

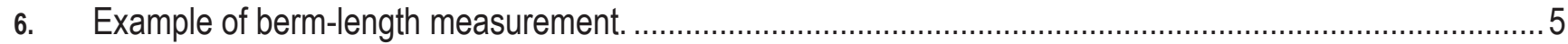

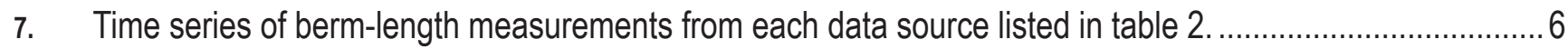

\section{Tables}

1. Satellite multispectral and panchromatic image resolutions............................................................... 3

2. Southern section berm-length measurements. 


\title{
Change in the Length of the Southern Section of the Chandeleur Islands Oil Berm, January 13, 2011, through September 3, 2012
}

\author{
By N.G. Plant and K.K. Guy
}

\section{Introduction}

On April 20, 2010, an explosion on the Deepwater Horizon oil rig drilling at the Macondo Prospect site in the Gulf of Mexico resulted in a marine oil spill that continued to flow through July 15, 2010. One of the affected areas was the Breton National Wildlife Refuge, which consists of a chain of low-lying islands, including Breton Island and the Chandeleur Islands, and their surrounding waters. The island chain is located approximately 115-150 kilometers $(\mathrm{km})$ north-northwest of the spill site (fig. 1). A sand berm was constructed seaward of, and on, the island chain. Construction began at the northern end of Chandeleur Islands in June 2010 and ended in April 2011 after $14 \mathrm{~km}$ of berm had been constructed. The berm consisted of three distinct sections based on where the berm was placed relative to the islands (fig. 2). The northern section of the berm was built in open water on a submerged portion of the Chandeleur Islands platform. The middle section was built approximately 70-90 meters (m) seaward of the Chandeleur Islands. The southern section was built on the islands' beaches. Repeated Landsat and SPOT satellite imagery and airborne light detection and ranging (lidar) were used to observe the disintegration of the berm over time. The methods used to analyze the remotely sensed data and the resulting, derived data for the southern section (fig. 3) are reported here.

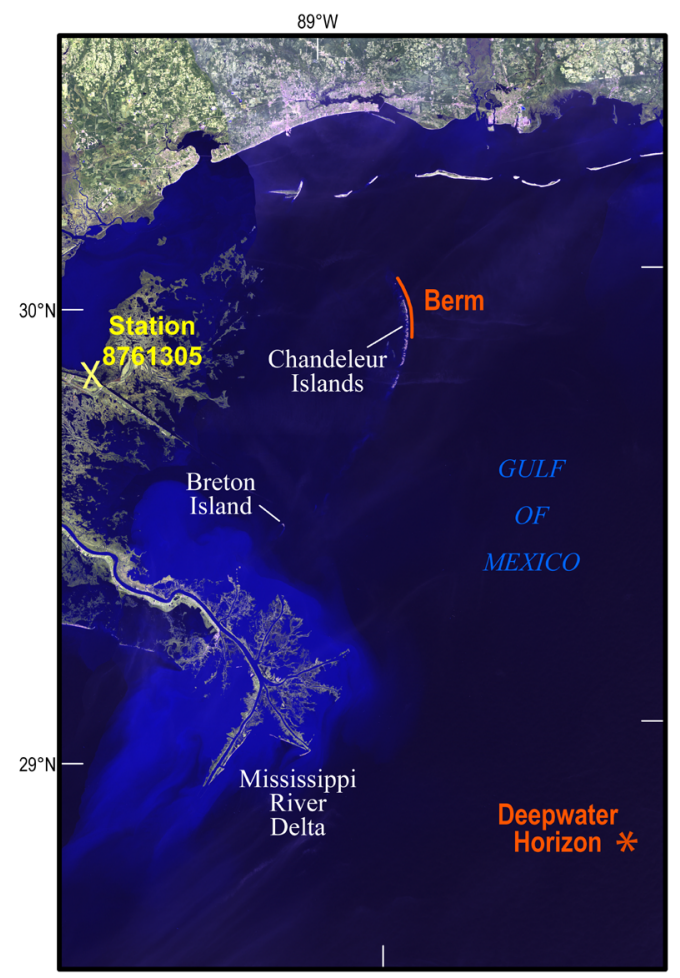

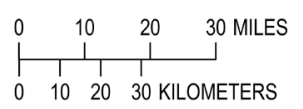

Base from U.S. Geological Survey Landsat 5, Feb 18, 2010 WGS 1984 UTM Zone $16 \mathrm{~N}$

Figure 1. Chandeleur and Breton Islands (part of the Breton Island National Wildlife Refuge), the Mississippi River Delta, the site of the Deepwater Horizon oil spill, and the location of the full extent of the Chandeleur Islands berm. The background image is U.S. Geological Survey Landsat 5 taken February 18, 2010, prior to the start of berm construction. 

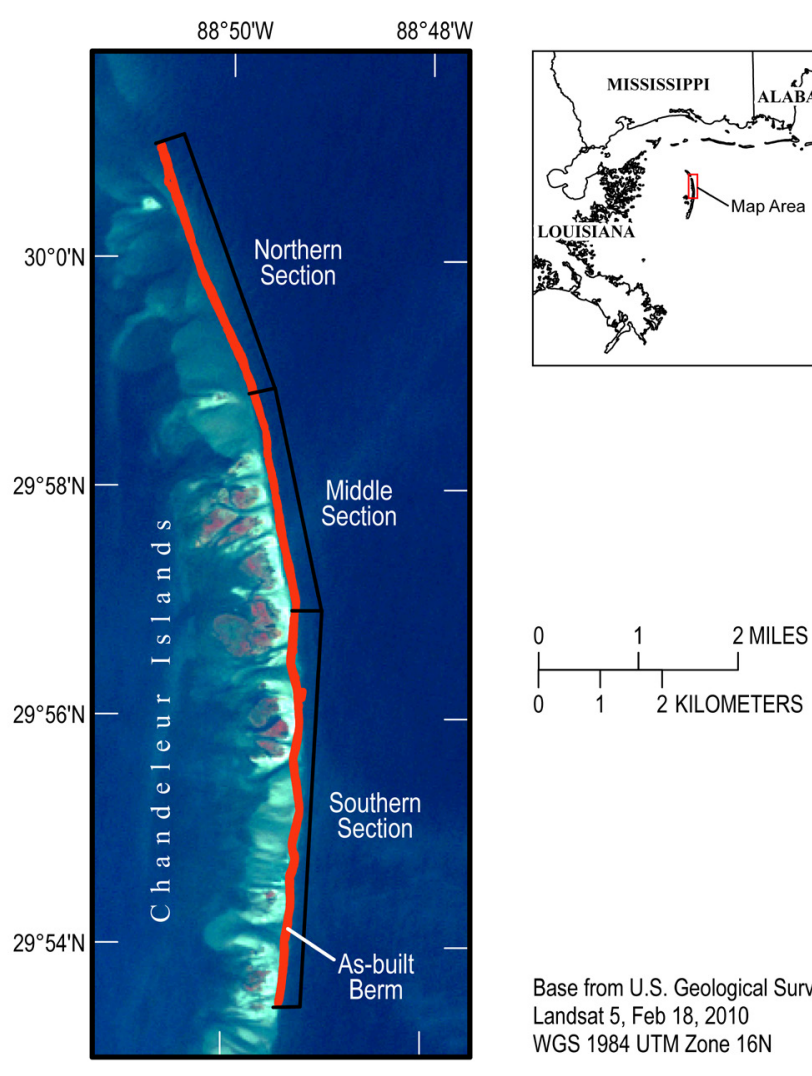

Base from U.S. Geological Survey Landsat 5, Feb 18, 2010 WGS 1984 UTM Zone 16N
Figure 2. The Chandeleur Islands berm divided into northern, middle, and southern sections. The as-built berm footprint is shown in orange. The background image is U.S. Geological Survey Landsat 5 taken February 18,2010 , prior to the start of berm construction.

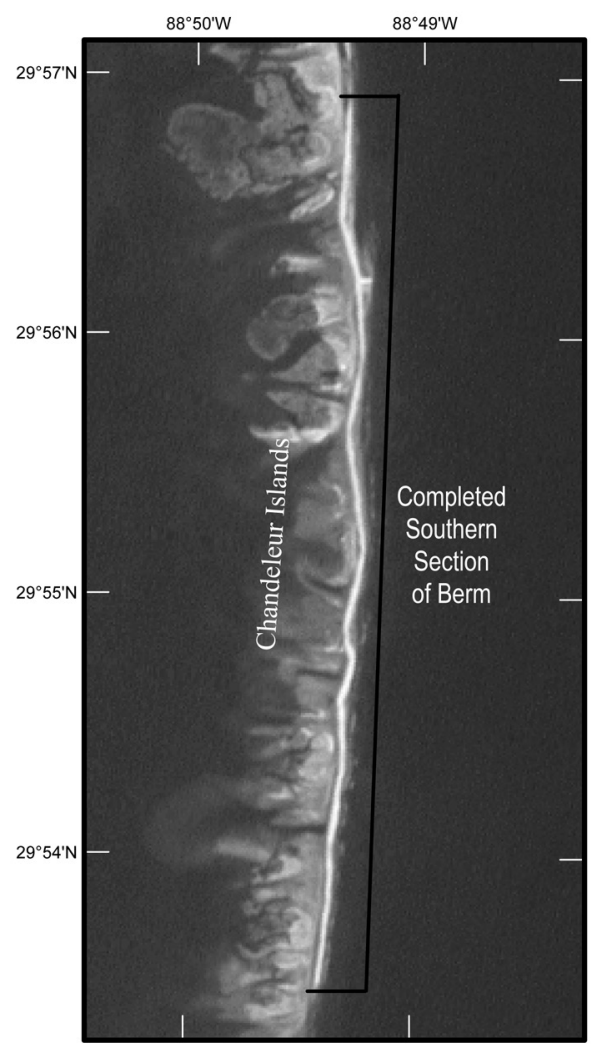

Base from U.S. Geological Survey Landsat 7, April 2, 2011

WGS 1984 UTM Zone 16N
Figure 3. The completed southern section of the Chandeleur Islands berm. This U.S. Geological Survey Landsat 7 image was taken April 2, 2011. 


\section{Methods}

The Chandeleur Islands berm was built approximately 50 meter $(\mathrm{m})$ wide (above mean high water) and $2 \mathrm{~m}$ high relative to the North American Vertical Datum of 1988 (NAVD 88) and using the 1996 Geoid model (Geoid 96). The large size of the berm, combined with the highly reflective nature of sand, made observations from satellite imagery possible. Medium resolution (5-20 m) SPOT satellite imagery (table 1; Centre National d'Etudes Spatiales, 2009) provided relatively frequent observation opportunities. Additionally, three high resolution lidar elevation datasets were used to observe the berm. The lidar data were collected on February 12, 2011, May 31, 2011, and February 6, 2012 (table 2) utilizing three different lidar systems: U.S. Geological Survey's topographic and bathymetric system (EAARL, McKean and others, 2009), U.S. Army Corps of Engineers topographic system (CHARTS, Wozencraft and Millar, 2005), and a contract topographic system (Digital Aerial Solutions using Leica ALS60, Bonisteel-Cormier, J. M., U.S. Geological Survey, written commun., 2013.).

A total of 26 observations were made starting January 13, 2011, prior to completion of the southern section but after the first evidence of deterioration had appeared. The observations continued to September 3, 2012, when the berm no longer occupied its as-built footprint. For the purpose of these berm length measurements, only those portions of the berm that occupied its as-built footprint (as estimated from a sequence of SPOT satellite images obtained during the construction period: September 5, 2010; October 1, 2010; December 7, 2010; and April 3, 2011) were measured.

Table 1. Satellite multispectral and panchromatic image resolutions.

$[\mathrm{m}, \mathrm{meter}]$

\begin{tabular}{ccc}
\hline Satellite & Multispectral resolution & Panchromatic resolution \\
\hline SPOT 4 & $20 \mathrm{~m}$ & $10 \mathrm{~m}$ \\
SPOT 5 & $10 \mathrm{~m}$ & $5 \mathrm{~m}$ \\
\hline
\end{tabular}

SPOT satellite images were selected on the basis of availability, clear view of the berm, and resolution (ground sampling interval or cell size). When available, panchromatic bands were used because of their higher resolutions. When not available, band 1 ( 0.50 to 0.59 micrometer $[\mu \mathrm{m}])$ from the multispectral images was selected (table 2). Landsat images did not reliably identify the section of berm that was built on the subaerially exposed island.

Water has lower reflectivity than sand in the satellite images and, therefore, has a lower pixel-intensity value. In a typical gray-scale representation where low values are dark and high values are light, water will appear dark and sand will appear very light or white. Wet sand is less reflective than dry sand and appears in mid-tone grays (fig. 4). The relatively high pixel-intensity values of dry sand were used to delimit the berm footprint. This method is subject to bias errors caused by differences in water levels when different images were acquired, and no corrections for these biases have been made here. The water levels from nearby National Oceanic and Atmospheric Administration (NOAA) station 8761305 (fig. 1) (http://www.ndbc.noaa.gov/station page.php? station=shbll), referenced to the mean sea level datum, are included in this report (table 2).

Each image was visually examined to determine the footprint of the berm. Isolines based on a contour interval of 5 pixel-intensity values (fig. 5) were generated for each image using the Contour tool

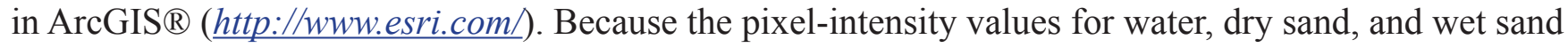
were not consistent between images, fixed contour levels were not used to delineate the berm. Instead, the contours were overlaid on the image and one of these contours was selected to represent the berm footprint as a polygon in the geographic information system (GIS). Occasionally, the polygons were 
manually edited to separate the berm from the beach. This footprint was then used to measure the length of the berm segment. Only those portions of the berm footprint that occupied the original as-built footprint were used to measure berm length (fig. 6). Once sand was moved beyond the as-built footprint by overwash, inundation, or breaching, it no longer contributed to the measured length of the berm.

The berm footprints obtained from three lidar elevation datasets were based on elevation rather than reflectivity. Contours were generated at 10-centimeter $(\mathrm{cm})$ intervals and were compared to the berm footprints obtained from satellite imagery. The 100-cm (NAVD 88, Geoid 96) contour was selected to represent the subaerial portion of the berm. This level is above the typical water level, allowing retrieval of topographic lidar from each survey. Similarly to the treatment of the satellite imagery, bermlength measurements were estimated where the $100-\mathrm{cm}$ lidar-elevation contour fell within the as-built footprint. Some clusters of small polygons appeared in the lidar berm footprints. These clusters were measured as if they were one large polygon.

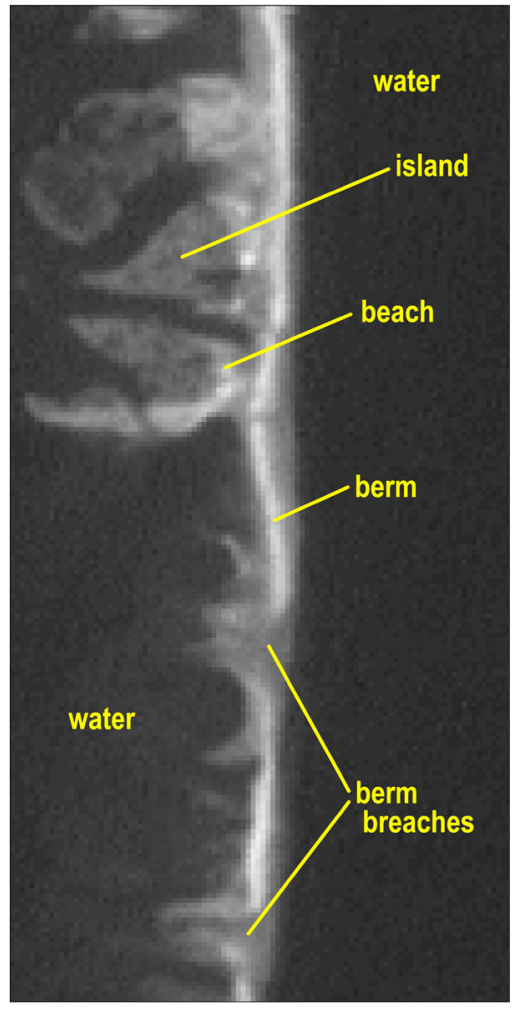

Figure 4. Example of a panchromatic image. Water, island, beach, berm, and breaches in the berm are labeled. The dry sand berm appears as light grays to white, the water as darker shades of gray, and wet sand (for example, at the berm breaches) as mid-tone grays.

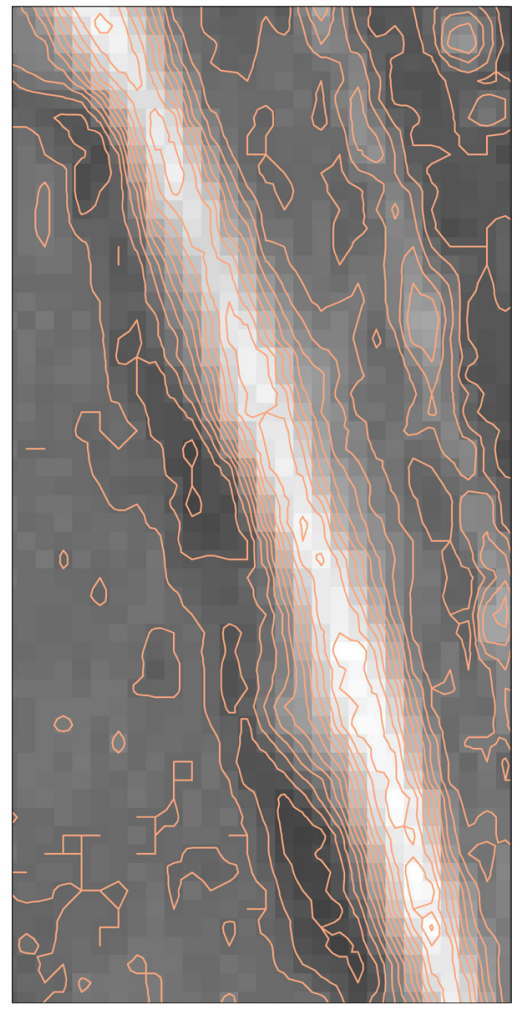

Figure 5. Example of isolines generated on the basis of pixel value. The isolines are drawn in pink on top of the panchromatic image from which they were made. The berm is the wide, light streak of pixels running from the upper left to the lower right of the figure. The mid-tone grays in the upper right are waves. 


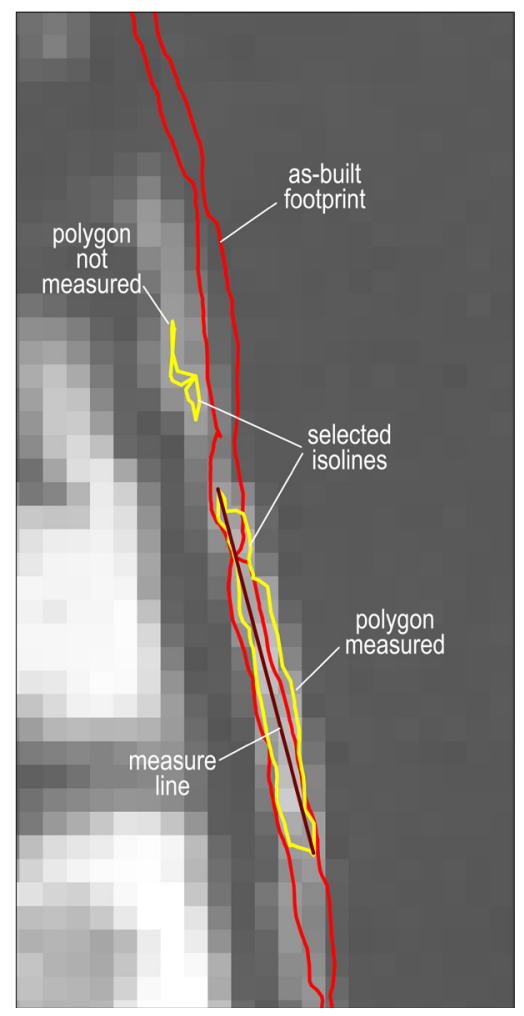

Figure 6. Example of berm-length measurement. The red line represents the berm's as-built footprint. The yellow lines represent the contour selected to represent the berm footprint. One yellow line encloses a small area that appears to be on the berm; however, this area does not fall within the as-built footprint. Therefore, this area is no longer considered part of the berm and is not measured. A second yellow line encloses a larger area and mostly falls within the as-built footprint. The brown line represents the resulting berm-length measurement.

\section{Results}

The results from the satellite and lidar data analysis are presented in figure 7, which shows a time series of berm lengths derived from each of the sensors. The measurements are listed in table 2. The accuracy of the berm-length measurements was quantified from the differences between sequential length measurements, excluding the period of large length increases from January 13 through April 3, 2011, associated with berm construction, the large changes observed on September 6 and 9, 2011, that were associated with tropical storm Lee, and the large change between May and June 2012. The root mean square difference was $595 \mathrm{~m}$. The SPOT-5 data were not as consistent as the SPOT-4 data, and the root mean square difference using only SPOT-4 data was $325 \mathrm{~m}$. 


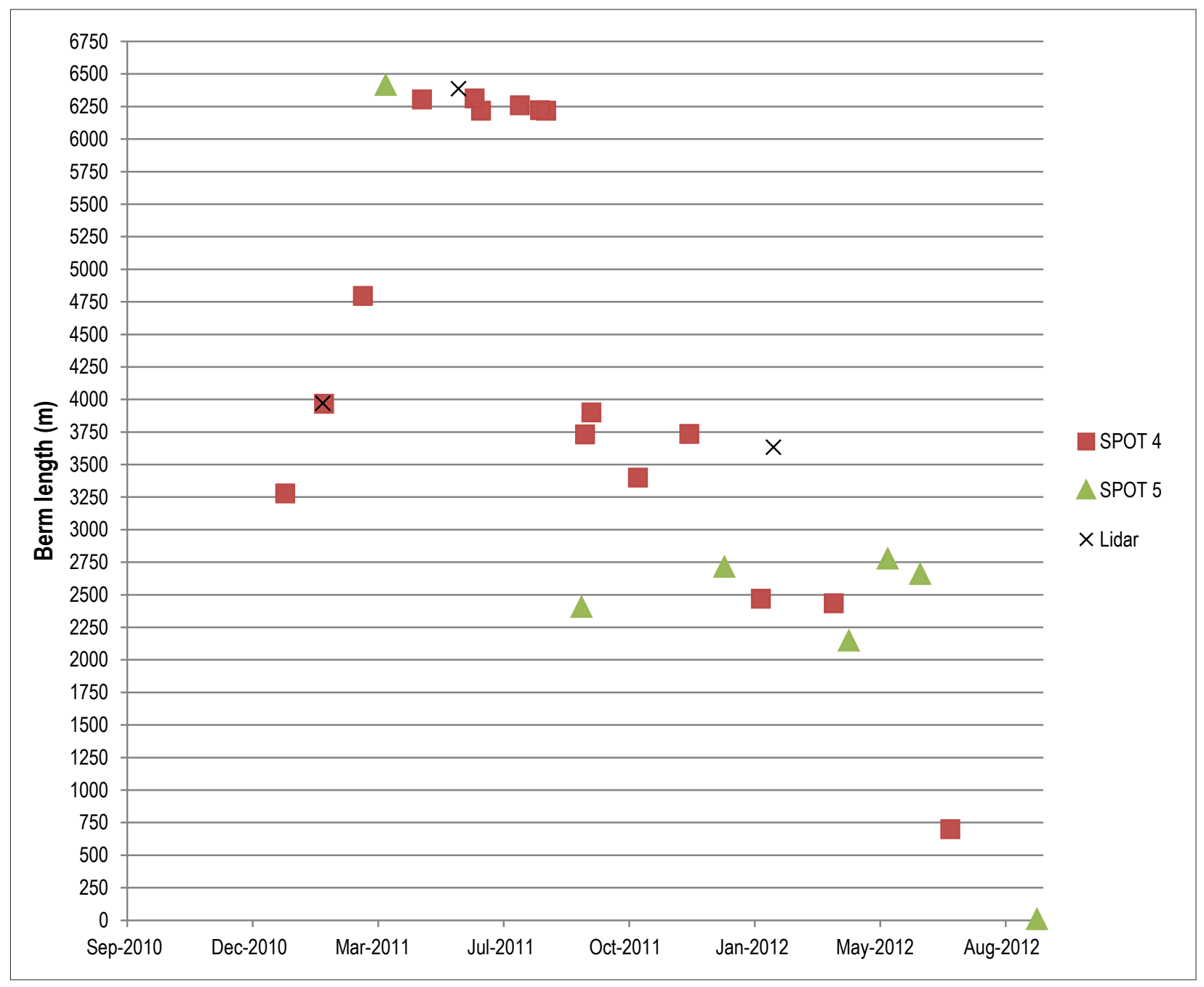

Figure 7. Time series of berm-length measurements from each data source listed in table 2. 
Table 2. Southern section berm-length measurements.

\begin{tabular}{|c|c|c|c|c|c|c|c|c|c|c|}
\hline Date (MDY) & $\begin{array}{l}\text { Image Time } \\
\text { (UT) }\end{array}$ & Sensor & Spectrum & Isoline & $\begin{array}{c}\text { Number of } \\
\text { Line Segments }\end{array}$ & $\begin{array}{l}\text { Total Berm } \\
\text { Length }(m)\end{array}$ & $\begin{array}{c}\text { Length } \\
\text { Constructed } \\
(\mathrm{m})\end{array}$ & $\begin{array}{l}\text { Water Level } \\
\text { (m) }\end{array}$ & $\begin{array}{l}\text { Area of Isoline } \\
\text { Polygons }\left(\mathrm{m}^{2}\right)\end{array}$ & $\begin{array}{c}\text { Area of Berm } \\
\left(\mathrm{m}^{2}\right)\end{array}$ \\
\hline $1 / 13 / 2011$ & $16: 20$ & SPOT 4 & pan & 165 & 1 & 3278 & 3278 & -0.32 & 156270.375 & 144096.789 \\
\hline $2 / 13 / 2011$ & 16.22 & SPOT 4 & pan & 170 & 1 & 3966 & 3966 & -0.67 & 187194.777 & 151276.286 \\
\hline $3 / 16 / 2011$ & 16.25 & SPOT 4 & pan & 245 & 2 & 4794 & 4828 & -0.09 & 222595.604 & 196023.373 \\
\hline $5 / 2 / 2011$ & $16: 19$ & SPOT 4 & pan & 155 & 1 & 6303 & 6439 & 0.25 & 229289.579 & 217231.858 \\
\hline $6 / 13 / 2011$ & $16: 09$ & SPOT 4 & pan & 60 & 2 & 6311 & 6439 & 0.34 & 289323.782 & 252503.793 \\
\hline $6 / 18 / 2011$ & $16: 13$ & SPOT 4 & pan & 80 & 2 & 6218 & 6439 & 0.07 & 227577.364 & 208837.792 \\
\hline $7 / 19 / 2011$ & $16: 15$ & SPOT 4 & pan & 185 & 3 & 6258 & 6439 & 0.24 & 247014.987 & 232466.615 \\
\hline 8/4/2011 & $16: 06$ & SPOT 4 & pan & 225 & 3 & 6222 & 6439 & 0.00 & 228779.258 & 217182.643 \\
\hline 8/9/2011 & $16: 10$ & SPOT 4 & pan & 220 & 2 & 6218 & 6439 & 0.06 & 265990.791 & 224417.576 \\
\hline 9/9/2011 & $16: 13$ & SPOT 4 & pan & 220 & 6 & 3730 & 6439 & 0.30 & 155210.928 & 135930.898 \\
\hline $9 / 14 / 2011$ & $16: 16$ & SPOT 4 & pan & 235 & 3 & 3899 & 6439 & -0.18 & 230645.437 & 160263.804 \\
\hline $10 / 21 / 2011$ & $16: 02$ & SPOT 4 & band 1 & 165 & 4 & 3400 & 6439 & 0.04 & 191410.659 & 138600.075 \\
\hline $12 / 1 / 2011$ & $16: 12$ & SPOT 4 & pan & 215 & 11 & 3735 & 6439 & 0.04 & 140905.615 & 123081.153 \\
\hline $1 / 27 / 2012$ & $16: 12$ & SPOT 4 & pan & 225 & 14 & 2468 & 6439 & -0.17 & 69018.868 & 59918.860 \\
\hline $3 / 25 / 2012$ & $15: 53$ & SPOT 4 & band 1 & 195 & 17 & 2434 & 6439 & 0.17 & 78397.018 & 64372.863 \\
\hline $6 / 26 / 2012$ & $15: 58$ & SPOT 4 & pan & 45 & 9 & 698 & 6439 & 0.65 & 19569.233 & 18920.243 \\
\hline 4/3/2011 & $16: 36$ & SPOT 5 & pan & 200 & 1 & 6408 & 6439 & -0.11 & 287210.266 & 282871.393 \\
\hline 9/6/2011 & $16: 34$ & SPOT 5 & pan & 180 & 22 & 2399 & 6439 & 0.56 & 41895.949 & 41812.496 \\
\hline $12 / 29 / 2011$ & $16: 40$ & SPOT 5 & pan & 190 & 17 & 2707 & 6439 & -0.17 & 103868.865 & 56730.271 \\
\hline 4/6/2012 & $16: 33$ & SPOT 5 & pan & 195 & 27 & 2139 & 6439 & 0.23 & 37472.992 & 36678.756 \\
\hline $5 / 7 / 2012$ & $16: 36$ & SPOT 5 & pan & 225 & 23 & 2769 & 6439 & 0.45 & 63353.307 & 60757.466 \\
\hline $6 / 2 / 2012$ & $16: 36$ & SPOT 5 & pan & 145 & 23 & 2652 & 6439 & 0.40 & 59509.428 & 54531.617 \\
\hline 9/3/2012 & $16: 44$ & SPOT 5 & band 1 & & 0 & 0 & 6439 & 0.03 & 0 & 0 \\
\hline $2 / 12 / 2011$ & & Lidar & elevation & $100 \mathrm{~cm}$ & 1 & 3970.580 & 3973 & & 176877.459 & 160069.918 \\
\hline $5 / 31 / 2011$ & & Lidar & elevation & $100 \mathrm{~cm}$ & 1 & 6386.600 & 6439 & & 236318.658 & 223167.496 \\
\hline $2 / 6 / 2012$ & & Lidar & elevation & $100 \mathrm{~cm}$ & 9 & 3633.281 & 6439 & & 103531.879 & 100833.811 \\
\hline
\end{tabular}

Date $(\mathrm{MDY})=$ Date in month/day/year format

Image Time $(\mathrm{UT})=$ Universal Time that image was acquired in hours and minutes (HH:MM)

Sensor $=$ Image source type

Spectrum $=$ The satellite image band used or, for lidar, the elevation used, in centimeters

Isoline (pixel value) = The "contour" line used as the berm footprint. The "contour" is based on pixel value for the satellite imagery and elevation for lidar

Number of Line Segments $=$ Number of line segments in berm measurement

Total Berm Length $(\mathrm{m})=$ Total length of berm, in meters

Length Constructed $(\mathrm{m})=$ Total length of berm constructed

Water Level $(\mathrm{m})=$ Water level Shell Beach, Louisiana, tide station, at the time of image collection, in meters, using Mean Sea Level as the datum

Area of Isoline Polygons $\left(\mathrm{m}^{2}\right)=$ Area of isoline polygons falling, at least in part, within the as-built footprint, in square meters

Area of Berm $\left(\mathrm{m}^{2}\right)=$ Area of the portion of the isoline polygons that fall within the as-built footprint, in square meters 


\section{References}

Centre National d'Etudes Spatiales (CNES) (2009), SPOT Looking down on Earth, at http://www.cnes.fr/web/CNES-en/1415-spot.php

McKean, J., Nagel, D., Tonina, D., Bailey, P., Wright, C. W., Bohn, C., and Nayegandhi, Amar, 2009, Remote sensing of channels and riparian zones with a narrow-beam aquatic-terrestrial LIDAR: Remote Sensing, v. 1, no. 4, p. 1065-1096.

Wozencraft, J., and Millar, D., 2005, Airborne lidar and integrated technologies for coastal mapping and nautical charting: Marine Technology Society Journal, v. 39, no. 3, p. 27-35.

\section{Acknowledgments}

The data collection and analysis presented in this report were conducted with support from the U.S. Geological Survey's Coastal and Marine Geology Program. The clarity of the report was improved by reviews from C. Sherwood and J. Flocks. We thank B. Boynton, T. Burress, and K. Waltenbaugh for editing, producing, and publishing the final document. 